\title{
Histological Grade: Analysis of Prognosis of Non-small Cell Lung Cancer After Complete Resection
}

\author{
MOTOAKI YASUKAWA ${ }^{1}$, NORIYOSHI SAWABATA ${ }^{1}$, TAKESHI KAWAGUCHI ${ }^{1}$, \\ NORIKAZU KAWAI ${ }^{1}$, TOKIKO NAKAI ${ }^{2}$, CHIHO OHBAYASHI ${ }^{2}$ and SHIGEKI TANIGUCHI ${ }^{1}$ \\ Departments of ${ }^{1}$ Thoracic and Cardiovascular Surgery, and ${ }^{2}$ Diagnostic Pathology, \\ Nara Medical University School of Medicine, Kashihara, Japan
}

\begin{abstract}
Background/Aim: Although the 2015 World Health Organization Classification reported that histological grading may be helpful in lung cancer management, a widely accepted histological grading system with clearly defined criteria and demonstrable clinical significance has not been developed. We investigated the prognoses of patients with resected non-small cell lung cancer (NSCLC) to identify prognostic factors, especially histological grade. Materials and Methods: The medical records of 531 patients between 2010 and 2015 were retrospectively reviewed. Overall survival (OS) curve was plotted using the Kaplan-Meier method. Cox regression analyses were used to evaluate the hazard ratio (HR) with endpoint of OS. Results: The 5-year OS rate in groups with histological grade 1, grade 2, and grade 3+4 groups was $95.8 \%, 85.7 \%$, and $72.1 \%$, respectively $(p<0.001)$. Multivariate analysis identified histological grade and vascular invasion as independent predictors of OS [histological grade: $H R=1.533$, $p=0.002]$. Conclusion: Histological grade was an independent prognostic factor of patients resected for all stages of NSCLC.
\end{abstract}

Among all new cancer cases worldwide, lung cancer accounts for approximately $13 \%$, and lung cancer mortality has remained the highest of all cancer types during the past several decades (1). Although diagnostic and therapeutic technologies have advanced rapidly $(2,3)$, the overall 5 -year survival rate of patients with non-small cell lung cancer (NSCLC) is still low at 15\% (4). NSCLC has a poor prognosis because of its rapid progression and lack of early-

This article is freely accessible online.

Correspondence to: Motoaki Yasukawa, Department of Thoracic and Cardiovascular Surgery, Nara Medical University School of Medicine, Kashihara, Nara 634-0813, Japan. Tel: +81 744223051, Fax: +81 744248040, e-mail: myasukawa@naramed-u.ac.jp

Key Words: Non-small cell lung carcinoma, histological grade, prognosis. stage symptoms (4). In order to detect NSCLC and determine its prognosis, practical and accurate biomarkers for NSCLC must be identified $(5,6)$. Although the 2015 World Health Organization (WHO) Classification of lung tumors reported that histological grading may be helpful for lung cancer management (7), a widely accepted histological grading system with clearly defined criteria and demonstrable clinical significance has not yet been developed for lung cancer, and more evidence than presented in the WHO report is needed (8). In 2011, the International Association for the Study of Lung Cancer, the American Thoracic Society, and the European Respiratory Society (IASLC/ATS/ERS) proposed a new classification of lung adenocarcinoma based simply on histological subtypes (9). Several reports on lung adenocarcinoma have demonstrated that this histological grading, based on architectural subtypes has implications beyond just predicting prognosis (10-12). Although previous studies have demonstrated that stage I lung adenocarcinoma can be prognostically stratified using architectural patterns, the prognostic value of architectural subtypes in more advanced stages of lung adenocarcinoma remains unclear (13). Weichert et al. proposed a grading system for lung squamous cell carcinoma in which the scores for two independent prognostic markers, including tumor budding and tumor-cell nest size, are summed (14). It has become important to determine whether histological grading should be performed with either one system for all tumor types or a separate system for each histological type (8). Therefore, we assessed the histological grade of NSCLC tumors based on a conventional histological criterion: tumor cell differentiation. We examined whether one histological grading system can be a prognostic factor for all stages and all types of completely resected NSCLC. This study retrospectively reviewed our Institutional experience and analyzed the outcomes of 531 patients who underwent complete resection of NSCLC of all stages, focusing especially on conventional histological grading based on tumor cell differentiation. 


\section{Materials and Methods}

Among 739 patients who underwent NSCLC resection at the Nara Medical University Hospital from January 2010 to December 2015, 531 patients who underwent lobectomy or more with systematic lymphadenectomy were enrolled in this study. The medical record of each patient was reviewed, and the pathological (p) $\mathrm{T}$ descriptor was reclassified based on the eighth edition of the tumor, node, and metastasis (TNM) staging $(15,16)$. The histological grade was not reclassified based on the eighth edition of the TNM staging or on the fourth edition of the WHO classification (7) but was classified based on tumor cell differentiation as well-differentiated NSCLC: grade 1; moderately differentiated NSCLC: grade 2; poorly differentiated NSCLC: grade 3; and undifferentiated NSCLC: grade 4. The exclusion criterion for entry into the study population was the presence of other concomitant malignant diseases.

Video-assisted thoracoscopic surgery was utilized to resect the lung tumors. This involved three incisions: an incision along the anterior axillary line for a camera port in the seventh or eighth intercostal space, a $1-\mathrm{cm}$ incision along the anterior axillary line in the fourth or fifth intercostal space, and a 4-to 5-cm incision in the axilla for a working port in the fourth or fifth intercostal space.

Follow-up examinations were symptom-oriented, but all patients underwent medical checkups and chest X-ray examinations at least twice a year and whole-body computed tomographic scans at least once a year. The observation period was terminated on 31 December 2017.

The Ethics Review Board of our Institute approved the study protocol (No. 1774) and waived the requirement to obtain written informed consent from patients because individual patients were not identified in this retrospective study.

Either the Chi-square test or Fisher's exact test was used, as appropriate, to analyze correlations between the two groups. Overall survival curves and recurrence-free survival curves were plotted using the Kaplan-Meier method, and the statistical significance of differences between groups was determined by the log-rank test. Univariate and multivariate Cox regression analyses were used to evaluate the hazard ratio with the endpoint of overall survival (period from the day of the operation to the day of death) or recurrence-free survival. The covariates considered were: age, sex, pathological diameter of tumor infiltration, tumor location, ground glass nodules on computed tomography, pT descriptor, $\mathrm{pN}$ descriptor, histological type, histological grade (tumor cell differentiation), pleural invasion factor, vascular invasion factor, lymphatic vessel invasion factor, pStage, and preoperative carcinoembryonic antigen (CEA) concentration. All $p$-values were two-sided, and $p$-values of 0.05 or less were considered to indicate a statistically significant difference. All analyses were conducted using EZR on R commander version 1.33 (Jichi Medical University, Saitama, Japan) (17).

\section{Results}

During follow-up (median $=47$ months; range $=1-91$ months), NSCLC recurrence was identified in $24.1 \%$ (128/531) and death occurred in $10.5 \%(56 / 531)$ of patients overall. The overall 5-year survival rate was $86.5 \%$ [95\% confidence interval $(\mathrm{CI})=82.4-89.5 \%]$, and the 5 -year recurrence-free survival rate was $68.6 \%(95 \% \mathrm{CI}=63.0-73.5 \%)$. Table I shows the clinicopathological characteristics of all patients. Table II shows the clinicopathological characteristics of the patients in the groups with and without recurrence. A larger tumor diameter, lymph node metastasis, pleural invasion, lymphovascular involvement, a high preoperative CEA concentration, and tumors with high-grade malignancy were more frequently observed in the group with recurrence than in the non-recurrence group (Fisher's exact test).

In total, there were 203 patients $(38.2 \%)$ with grade 1 NSCLC, 203 patients (38.2\%) with grade 2, 107 patients (20.2\%) with grade 3 , and 18 patients $(3.4 \%)$ with grade 4 NSCLC. Because there were only 18 patients in the latter group, they were added to the group with grade 3 NSCLC as a high-grade malignancy group (125 patients). In total, 3.0\% $(6 / 203)$ of patients in the grade 1 group, $10.8 \%(22 / 203)$ in the grade 2 group, and $22.4 \%(28 / 125)$ in the grade $3+4$ group died during the observation period.

The 5-year overall survival rate was $95.8 \%$ (95\% CI=89.798.4\%), $85.7 \%$ (95\% CI=78.5-90.7\%), and $72.1 \%(95 \%$ $\mathrm{CI}=61.2-80.5 \%)$ in the grade 1,2 , and $3+4$ groups, respectively $(p<0.001)$ (Figure 1$)$. The 5 -year recurrence-free survival rate in these groups was $92.9 \%$ (95\% CI=85.396.7\%), 56.0\% (95\% $\mathrm{CI}=45.4-65.3 \%)$, and $47.6 \%(95 \%$ $\mathrm{CI}=36.3-57.9 \%)$, respectively $(p<0.001)$ (Figure 2$)$.

Analysis of relative risks showed that male sex, greater pathological diameter of tumor infiltration, adenomatous histological type, higher histological grade, pleural invasion, lymphovascular involvement, higher $\mathrm{pT}$ and $\mathrm{pN}$ descriptors, higher pStage, and high preoperative CEA concentration were indicators of poorer overall survival. Multivariate analysis showed that histological grade and vascular invasion were independent predictors of overall survival (Tables III and IV). Conversely, the analysis of relative risk with the endpoint of cancer recurrence showed that greater pathological diameter of tumor infiltration, pure ground glass nodules on computed tomography, adenomatous histological type, pleural invasion, lymphovascular involvement, higher histological grade, higher $\mathrm{pT}$ and $\mathrm{pN}$ descriptors, higher pStage, and high preoperative CEA concentration were indicators of recurrence. Multivariate analysis showed that the $\mathrm{pN}$ descriptor, histological grade, and $\mathrm{v}$ factor were independent predictors of recurrence (Tables V and VI).

\section{Discussion}

In this study, the histological grade based on conventional histological tumor cell differentiation was shown to be an independent predictive factor of survival in patients with all stages of NSCLC. In general, the most significant predictor of recurrence and prognosis in patients with NSCLC is the cancer stage using the TNM classification, which also guides treatment decisions. Nevertheless, each stage remains a heterogeneous group comprising tumors with different 
Table I. Clinicopathological characteristics of all patients $(n=531)$.

\begin{tabular}{|c|c|}
\hline Characteristic & $\mathrm{N}(\%)$ \\
\hline \multicolumn{2}{|l|}{ Age } \\
\hline$<70$ Years & $265(49.9)$ \\
\hline$\geq 70$ Years & $266(50.1)$ \\
\hline \multicolumn{2}{|l|}{ Gender } \\
\hline Male & $334(62.9)$ \\
\hline Female & $197(37.1)$ \\
\hline \multicolumn{2}{|l|}{ CT findings } \\
\hline Pure GGN & $85(16.0)$ \\
\hline Other & $446(84.0)$ \\
\hline \multicolumn{2}{|l|}{ Location } \\
\hline Peripheral & $408(76.8)$ \\
\hline Other & $128(23.2)$ \\
\hline \multicolumn{2}{|l|}{ pStage } \\
\hline I & $378(71.2)$ \\
\hline$\geq \mathrm{II}$ & $153(28.8)$ \\
\hline \multicolumn{2}{|l|}{ pT descriptor } \\
\hline Tmin & $13(2.4)$ \\
\hline T1a & $29(5.5)$ \\
\hline $\mathrm{T} 1 \mathrm{~b}$ & $140(26.4)$ \\
\hline $\mathrm{T} 1 \mathrm{c}$ & $121(22.8)$ \\
\hline $\mathrm{T} 2 \mathrm{a}$ & $142(26.7)$ \\
\hline $\mathrm{T} 2 \mathrm{~b}$ & $43(8.1)$ \\
\hline$\geq \mathrm{T} 3$ & $43(8.1)$ \\
\hline \multicolumn{2}{|l|}{ Invasive size of tumor } \\
\hline$\leq 30 \mathrm{~mm}$ & $363(98.4)$ \\
\hline$>30 \mathrm{~mm}$ & $168(31.6)$ \\
\hline \multicolumn{2}{|l|}{ pN descriptor } \\
\hline $\mathrm{pN} 0$ & $436(82.1)$ \\
\hline $\mathrm{pN} 1$ & $52(9.8)$ \\
\hline$\geq \mathrm{pN} 2$ & $43(8.1)$ \\
\hline \multicolumn{2}{|l|}{ Histology } \\
\hline Adenocarcinoma & $383(72.1)$ \\
\hline Squamous cell carcinoma & $99(18.1)$ \\
\hline Other & $49(9.2)$ \\
\hline \multicolumn{2}{|l|}{ Histological grade } \\
\hline 1 & $203(38.2)$ \\
\hline 2 & $203(38.2)$ \\
\hline $3+4$ & $125(23.5)$ \\
\hline \multicolumn{2}{|l|}{ PL } \\
\hline Present & $131(24.7)$ \\
\hline Absent & $400(75.3)$ \\
\hline \multicolumn{2}{|l|}{ LY } \\
\hline Present & $243(45.8)$ \\
\hline Absent & $288(54.2)$ \\
\hline \multicolumn{2}{|l|}{$\mathrm{V}$} \\
\hline Present & $224(42.2)$ \\
\hline Absent & $307(57.8)$ \\
\hline \multicolumn{2}{|l|}{ CEA } \\
\hline$<5 \mathrm{ng} / \mathrm{ml}$ & $369(69.5)$ \\
\hline$\geq 5 \mathrm{ng} / \mathrm{ml}$ & $162(30.5)$ \\
\hline \multicolumn{2}{|l|}{ Recurrence } \\
\hline Yes & $128(24.1)$ \\
\hline No & $403(75.9)$ \\
\hline \multicolumn{2}{|l|}{ Survival } \\
\hline Yes & $475(89.5)$ \\
\hline No & $56(10.5)$ \\
\hline
\end{tabular}

CEA: Carcinoembryonic antigen, CT: computed tomographic; GGN ground glass nodule; LY: lymphatic vessel invasion factor; PL: pleural invasion factor, $\mathrm{V}$ : vascular invasion factor.
Table II. Univariate analysis of factors associated with recurrence considering all patients.

\begin{tabular}{|c|c|c|c|}
\hline Characteristic & $\begin{array}{l}\text { Without } \\
\text { recurrence } \\
(n=403)\end{array}$ & $\begin{array}{l}\text { With } \\
\text { recurrence } \\
(\mathrm{n}=128)\end{array}$ & $p$-Value \\
\hline \multicolumn{4}{|l|}{ Age } \\
\hline$<70$ Years & 206 & 59 & \multirow[t]{2}{*}{0.361} \\
\hline$\geq 70$ Years & 197 & 69 & \\
\hline \multicolumn{4}{|l|}{ Gender } \\
\hline Male & 248 & 86 & \multirow[t]{2}{*}{0.294} \\
\hline Female & 155 & 42 & \\
\hline \multicolumn{4}{|l|}{ CT findings } \\
\hline Pure GGN & 84 & 1 & \multirow[t]{2}{*}{0.521} \\
\hline Other & 319 & 127 & \\
\hline \multicolumn{4}{|l|}{ Location } \\
\hline Peripheral & 312 & 96 & \multirow[t]{2}{*}{0.631} \\
\hline Other & 91 & 32 & \\
\hline \multicolumn{4}{|l|}{ pStage } \\
\hline I & 328 & 50 & \multirow[t]{2}{*}{$<0.001 *$} \\
\hline$\geq$ II & 75 & 78 & \\
\hline \multicolumn{4}{|l|}{ pT descriptor } \\
\hline Tmin & 13 & 0 & \multirow[t]{7}{*}{ NA } \\
\hline $\mathrm{T} 1 \mathrm{a}$ & 26 & 3 & \\
\hline $\mathrm{T} 1 \mathrm{~b}$ & 126 & 14 & \\
\hline $\mathrm{T} 1 \mathrm{c}$ & 97 & 24 & \\
\hline $\mathrm{T} 2 \mathrm{a}$ & 88 & 54 & \\
\hline $\mathrm{T} 2 \mathrm{~b}$ & 25 & 18 & \\
\hline$\geq \mathrm{T} 3$ & 28 & 15 & \\
\hline \multicolumn{4}{|l|}{ Invasive size of tumor } \\
\hline$\leq 30 \mathrm{~mm}$ & 298 & 65 & \multirow[t]{2}{*}{$<0.001^{*}$} \\
\hline$>30 \mathrm{~mm}$ & 105 & 63 & \\
\hline \multicolumn{4}{|l|}{$\mathrm{pN}$ descriptor } \\
\hline pNO & 370 & 66 & \multirow[t]{3}{*}{$<0.001 *$} \\
\hline $\mathrm{pN} 1$ & 25 & 27 & \\
\hline$\geq \mathrm{pN} 2$ & 8 & 35 & \\
\hline \multicolumn{4}{|l|}{ Histology } \\
\hline Adenocarcinoma & 301 & 82 & \multirow[t]{3}{*}{$0.036^{*}$} \\
\hline Squamous cell carcinoma & 71 & 28 & \\
\hline Other & 31 & 18 & \\
\hline \multicolumn{4}{|l|}{ Histological grade } \\
\hline 1 & 193 & 10 & \multirow[t]{3}{*}{$<0.001 *$} \\
\hline 2 & 138 & 65 & \\
\hline $3+4$ & 72 & 53 & \\
\hline PL & & & \\
\hline Present & 72 & 59 & $<0.001 *$ \\
\hline Absent & 331 & 69 & \\
\hline LY & & & \\
\hline Present & 137 & 106 & $<0.001 *$ \\
\hline Absent & 266 & 22 & \\
\hline $\mathrm{V}$ & & & \\
\hline Present & 128 & 96 & $<0.001 *$ \\
\hline Absent & 275 & 32 & \\
\hline CEA & & & \\
\hline$<5 \mathrm{ng} / \mathrm{ml}$ & 303 & 66 & $<0.001 *$ \\
\hline$\geq 5 \mathrm{ng} / \mathrm{ml}$ & 100 & 62 & \\
\hline Survival & & & \\
\hline Yes & 391 & 84 & $<0.001 *$ \\
\hline No & 12 & 44 & \\
\hline
\end{tabular}

CEA: Carcinoembryonic antigen; CT: computed tomographic; GGN: ground glass nodule; LY: lymphatic vessel invasion factor; NA: not applicable; PL: pleural invasion factor, V: vascular invasion factor; * $p<0.05$. 


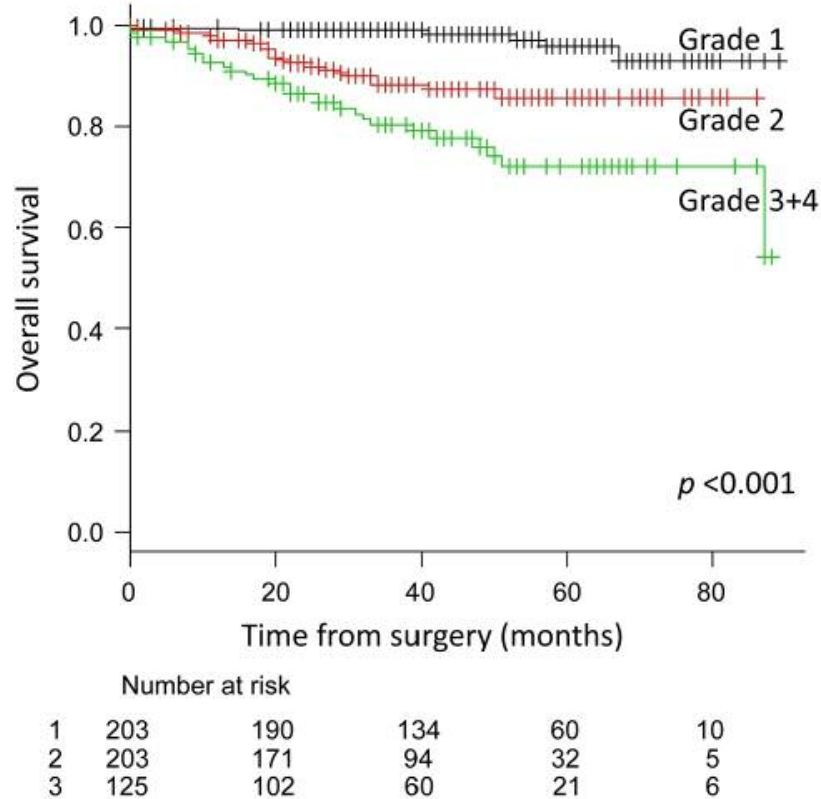

Figure 1. Overall survival curves for all patients according to histological grade $(G)$. The 5-year overall survival rates were $95.8 \%$ in $G 1,85.7 \%$ in $G 2$, and $72.1 \%$ in $G 3+4$ groups $(p<0.001)$.

responses to treatment and overall outcomes. Thus, a tumorrelated biological prognostic factor is needed.

Histological grading has prognostic implications. Histological parameters that are correlated with an unfavorable prognosis include high histological grade and vascular invasion $(18,19)$. Other potentially promising unfavorable prognostic indicators are increased mitotic activity, relatively few tumor-infiltrating lymphoid cells, and extensive tumor necrosis. In the third edition of the WHO classification (2004) (20), histological grading was described only for adenocarcinoma: "Grading is based on conventional histological criteria, including the extent to which the architectural pattern of the tumor resembles normal lung tissue, and cytologic atypia"; grades 1,2, and 3 refer to well, moderately, and poorly differentiated tumors, respectively. In other words, malignant grading depends on the degree of differentiation, including variations in histological architecture and cell atypia. The new fourth edition of the WHO classification (7) simply defined grade 1 (welldifferentiated; lepidic predominant), grade 2 (moderately differentiated; acinar or papillary predominant), and grade 3 (poorly differentiated; solid or micropapillary predominant) based on the single most predominant architectural pattern of an adenocarcinoma. For other histological types, histological grades are conventionally defined as grade 1 (well-differentiated), grade 2 (moderately differentiated), and

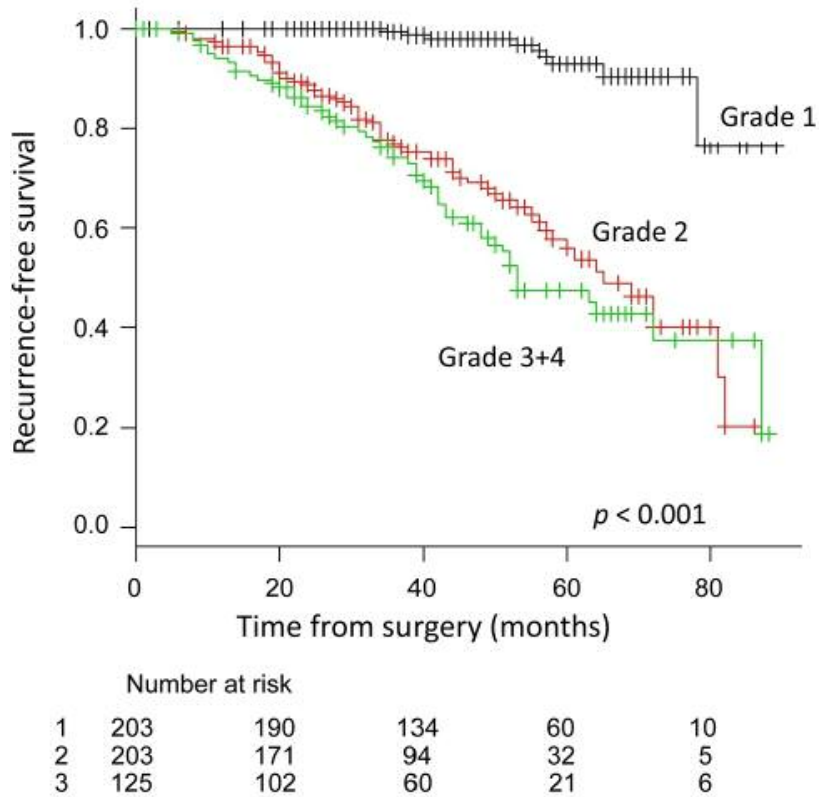

Figure 2. Recurrence-free survival curves for all patients according to histological grade $(G)$. The 5-year recurrence-free survival rates were $92.9 \%$ in $G 1,56.0 \%$ in $G 2$, and $47.6 \%$ in $G 3+4$ groups $(p<0.001)$.

grade 3 (poorly differentiated). Several studies have demonstrated that the invasive adenocarcinoma classification was related to the histological grade. Sica et al. proposed that histological grading by the new IASLC/ATS/ERS classification system provided good separation of patients with stage I lung adenocarcinoma in terms of disease-free survival, and it was more objective than the conventional grading by tumor differentiation (21). In addition, the current WHO classification system has a crucial flaw in that most adenocarcinomas $(>80 \%)$ are invasive tumors with highly heterogeneous components (20). The percentage of tumors with well to moderate differentiation was significantly higher in the lepidic predominant group, whereas the percentage with poor differentiation was significantly higher in the solid predominant group $(11,22,23)$.

Cellular proliferation is an important consideration in NSCLC because of its significant relationship with patient prognosis (24). Several studies have demonstrated that for lung adenocarcinoma, this histological grading based on architectural subtypes has implications beyond just predicting prognosis (11, 23). Yoshizawa et al. examined 514 patients with stage I adenocarcinoma and demonstrated that patients with the micropapillary-predominant subtype had a poor outcome (11). Furthermore, recent data suggest that the poorly differentiated solid and micropapillary histological subtypes are not only correlated with poor survival, but are also predictive of a 
Yasukawa et al: Histological Grade of NSCLC

Table III. Univariate analysis of factors influencing survival of all patients after complete resection of primary lung cancer.

\begin{tabular}{|c|c|c|c|c|}
\hline Factor & Comparison & Hazard ratio & $95 \% \mathrm{CI}$ & $p$-Value \\
\hline Age & $\geq 70$ vs. $<70$ years & 1.659 & $0.970-2.840$ & 0.065 \\
\hline Gender & Male $v s$. female & 2.401 & $1.268-4.548$ & $0.007 *$ \\
\hline CT findings & Pure GGN vs. other & $1.129 \times 10^{-8}$ & $0.000-$ Inf & 0.995 \\
\hline Location & Peripheral $v s$. other & 1.455 & $0.734-2.884$ & 0.283 \\
\hline Histological grade & $\mathrm{G} 2+3+4 v s . \mathrm{G} 1$ & 2.675 & $1.863-3.842$ & $<0.001 *$ \\
\hline pStage & I $v s . \geq \mathrm{II}$ & 0.463 & $0.266-0.806$ & $0.006^{*}$ \\
\hline $\mathrm{pT}$ & $\geq 2$ vs. $\leq 1$ & 3.684 & $2.062-6.581$ & $<0.001 *$ \\
\hline Histology & Adenocarcinoma $v s$. non-adenocarcinoma & 0.365 & $0.216-0.617$ & $0.006^{*}$ \\
\hline Invasive size of tumor & $>30 v s . \leq 30 \mathrm{~mm}$ & 3.182 & $1.876-5.399$ & $<0.001 *$ \\
\hline $\mathrm{pN}$ & $\geq 1$ vs. 0 & 1.934 & $1.391-2.688$ & $<0.001 *$ \\
\hline PL & Present $v s$. absent & 2.990 & $1.767-5.061$ & $<0.001 *$ \\
\hline $\mathrm{V}$ & Present $v s$. absent & 6.669 & $3.447-12.900$ & $<0.001 *$ \\
\hline LY & Present $v s$. absent & 4.752 & $2.509-9.000$ & $<0.001 *$ \\
\hline CEA & $\geq 5 \mathrm{vs} .<5 \mathrm{ng} / \mathrm{ml}$ & 2.284 & $1.351-3.863$ & $0.002 *$ \\
\hline
\end{tabular}

CEA: Carcinoembryonic antigen; CI: confidence interval; CT: computed tomographic; GGN: ground glass nodule; Inf: infinity; LY: lymphatic vessel invasion factor; PL: pleural invasion factor; V: vascular invasion factor; $* p<0.05$.

Table IV. Multivariate analysis of factors influencing survival of all patients after complete resection of primary lung cancer.

\begin{tabular}{|c|c|c|c|c|}
\hline & Comparison & Hazard ratio & $95 \% \mathrm{CI}$ & $p$-Value \\
\hline Gender & Male $v s$. female & 1.498 & $0.754-2.976$ & 0.249 \\
\hline Histological grade & $\mathrm{G} 2+3+4$ vs. G1 & 1.589 & $1.040-2.428$ & $0.032 *$ \\
\hline Histology & Adenocarcinoma $v s$. non-adenocarcinoma & 0.852 & $0.465-1.559$ & 0.603 \\
\hline pT & $\geq 2$ vs. $\leq 1$ & 1.400 & $0.648-3.025$ & 0.393 \\
\hline $\mathrm{pN}$ & $\geq 1$ vs. 0 & 1.319 & $0.902-1.929$ & 0.153 \\
\hline PL & Present $v s$. absent & 1.096 & $0.554-2.169$ & 0.791 \\
\hline $\mathrm{V}$ & Present $v s$. absent & 2.997 & $1.252-7.177$ & $0.014 *$ \\
\hline LY & Present vs. absent & 1.138 & $0.498-2.604$ & 0.759 \\
\hline CEA & $\geq 5 v s .<5 \mathrm{ng} / \mathrm{ml}$ & 1.486 & $0.856-2.581$ & 0.160 \\
\hline
\end{tabular}

CEA: Carcinoembryonic antigen; CI: confidence interval; LY: lymphatic vessel invasion factor; PL: pleural invasion factor; V: vascular invasion factor; ${ }^{*} p<0.05$. Likelihood ratio test: $p<0.001$, Wald test: $p<0.001$, Score test: $p<0.001$.

survival benefit with cisplatin-based adjuvant chemotherapy in patients with surgically-resected adenocarcinoma (12). However, although previous studies have demonstrated that stage I adenocarcinoma can be prognostically stratified using architectural patterns, the prognostic value of architectural subtypes in more advanced stages of lung adenocarcinoma remains unclear (13). Weichert et al. proposed a grading system for lung squamous cell carcinoma based on a scoring system in which the scores for two independent prognostic markers (tumor budding and tumor cell nest size) are summed (14). This scoring system demonstrated prognostic significance for overall survival by univariate and multivariate analyses. Although some histological grading systems are available for NSCLC, a widely accepted histological grading system with clearly defined criteria and demonstrable clinical significance has not been developed (8). Accurate determination of histological differentiation might be difficult. In the eighth version of the UICC (16) and fourth edition of the WHO classification (7), the histological grading systems are defined in addition to adenocarcinoma. This definition has a problem, namely the grading of lung adenocarcinoma using architectural versus nuclear approaches or a combination of both. This definition is obscure and makes grading confusing, and it may cause pathologists to rely on subjective judgments. Furthermore, it has become important to determine whether histological grading should be performed using one system for all types or separate systems for each histological type (8). There is a need to establish a grading system for lung cancer using resected specimens like the systems used for carcinomas of the breast (25), prostate (26), and kidney (27). 
in vivo $32: 1505-1512(2018)$

Table V. Univariate analysis of factors influencing recurrence in all patients after complete resection of primary lung cancer.

\begin{tabular}{|c|c|c|c|c|}
\hline Factor & Comparison & Hazard ratio & $95 \% \mathrm{CI}$ & $p$-Value \\
\hline Age & $\geq 70$ vs. $<70$ years & 1.345 & $0.949-1.906$ & 0.095 \\
\hline Gender & Male $v s$. female & 1.381 & $0.955-1.998$ & 0.087 \\
\hline CT findings & Pure GGN vs. other & 0.039 & $0.005-0.281$ & $0.001^{*}$ \\
\hline Location & Peripheral vs. other & 1.013 & $0.679-1.514$ & 0.948 \\
\hline Histological grade & $\mathrm{G} 2+3+4$ vs. G1 & 2.468 & $1.962-3.106$ & $<0.001 *$ \\
\hline pStage & I $v s . \geq \mathrm{II}$ & 5.199 & $3.637-7.432$ & $<0.001 *$ \\
\hline pT & $\geq 2 v s . \leq 1$ & 3.230 & $2.228-4.684$ & $<0.001 *$ \\
\hline Histology & Adenocarcinoma $v s$. non-adenocarcinoma & 0.603 & $0.420-0.865$ & $0.006^{*}$ \\
\hline Invasive size of tumor & $>30$ vs. $\leq 30 \mathrm{~mm}$ & 2.744 & $1.937-3.886$ & $<0.001 *$ \\
\hline $\mathrm{pN}$ & $\geq 1$ vs. 0 & 2.871 & $2.364-3.488$ & $<0.001 *$ \\
\hline PL & Present $v s$. absent & 2.673 & $1.883-3.795$ & $<0.001 *$ \\
\hline $\mathrm{V}$ & Present $v s$. absent & 5.226 & $3.501-7.800$ & $<0.001 *$ \\
\hline LY & Present $v s$. absent & 6.215 & $3.925-9.840$ & $<0.001 *$ \\
\hline CEA & $\geq 5 \mathrm{vs.}<5 \mathrm{ng} / \mathrm{ml}$ & 2.284 & $1.613-3.235$ & $<0.001 *$ \\
\hline
\end{tabular}

CEA: Carcinoembryonic antigen; CI: confidence interval; CT: computed tomographic; GGN: ground glass nodule; LY: lymphatic vessel invasion factor; PL: pleural invasion factor; V: vascular invasion factor; ${ }^{*} p<0.05$.

Table VI. Multivariate analysis of factors influencing recurrence of all patients after complete resection of primary lung cancer.

\begin{tabular}{|c|c|c|c|c|}
\hline Factor & Comparison & Hazard ratio & $95 \% \mathrm{CI}$ & $p$-Value \\
\hline CT findings & Pure GGN vs. other & 0.190 & $0.025-1.423$ & 0.106 \\
\hline Histological grade & $\mathrm{G} 2+3+4$ vs. G1 & 1.533 & $1.173-2.005$ & $0.002 *$ \\
\hline Histology & Adenocarcinoma vs. non-adenocarcinoma & 1.126 & $0.753-1.685$ & 0.562 \\
\hline pT & $\geq 2 v s . \leq 1$ & 1.441 & $0.865-2.403$ & 0.161 \\
\hline $\mathrm{pN}$ & $\geq 1 v s .0$ & 1.988 & $1.573-2.512$ & $<0.001 *$ \\
\hline PL & Present $v s$. absent & 0.813 & $0.505-1.310$ & 0.396 \\
\hline $\mathrm{V}$ & Present $v s$. absent & 2.296 & $1.363-3.868$ & $0.002 *$ \\
\hline LY & Present $v s$. absent & 1.417 & $0.779-2.576$ & 0.253 \\
\hline CEA & $\geq 5 \mathrm{vs} .<5 \mathrm{ng} / \mathrm{ml}$ & 1.360 & $0.944-1.958$ & 0.099 \\
\hline
\end{tabular}

CEA: Carcinoembryonic antigen; CI: confidence interval; CT: computed tomographic; GGN: ground glass nodule; LY: lymphatic vessel invasion factor; PL: pleural invasion factor; V: vascular invasion factor. Likelihood ratio test: $p<0.001$, Wald test: $p<0.001$, Score test: $p<0.001$. CEA: carcinoembryonic antigen, CI: confidence interval, GGN: ground glass nodule, ${ }^{*} p<0.05$.

In this study, several pathologists determined the histological grades by emphasizing on cell differentiation. The histological grade based on conventional histological criteria was an independent predictor of prognosis and recurrence for all stages and histological types. These results imply that the histological grade might actually reflect the biological malignancy of the tumor itself. Furthermore, our multivariate analysis did not identify the $\mathrm{pT}$ or $\mathrm{pN}$ descriptor as independent predictors of prognosis, although the univariate analysis did. We assume that although the pTNM classification only shows advanced-stage cancer when NSCLC has been resected, this classification does not always accurately reveal the tumor cell biological malignancy because of clinical, pathological, and molecular heterogeneity. However, the histological grade and vascular invasion factor might reflect therapeutic efficacy after recurrence. Histological grading based on tumor cell differentiation is very useful in assessing the prognosis of NSCLC. Although it is a traditional grading system, it is simple and practical regardless of the histological type of NSCLC.

In this study, we investigated the relationship between prognosis and histological grade and demonstrated that histological grade was a prognostic factor of NSCLC. We assume that the histological grade can reflect the biological malignancy of NSCLC and serve as a simple biomarker for NSCLC. Furthermore, we believe that the conventional histological grading system could be an acceptable prognostic factor for all stages of resectable NSCLC.

This study has two main limitations: its retrospective design and small sample size. The histological grades were 
not reclassified based on the fourth edition of the WHO classification (7) or eighth edition of TNM staging (16) within the study period because of assessment of conventional histological grading system for all histological types of NSCLC, and examination as to whether one grading system can be a prognostic factor for all histological types of completely resected NSCLC. More validation studies are needed before an appropriate grading system can be recommended, not only for lung adenocarcinoma but also for all histological types of NSCLC.

In summary, we found that conventional histological grading is a prognostic factor for completely resected NSCLC, despite the aforementioned limitations of this study. There is a great need for additional investigation of histological grading in order to determine a simple and clear-cut classification that reflects prognosis or treatment. Studies involving a large, multi-institutional cohort will be important to validate these findings. Further investigation is required to determine the relationship between prognosis and histological grade.

\section{Conflicts of Interest}

The Authors declare that they have no conflict of interest in regard to this study.

\section{References}

1 Torre LA, Bray F, Siegel RL, Ferlay J, Lortet-Tieulent J and Jemal A: Global cancer statistics, 2012. CA Cancer J Clin 65: 87-108, 2015.

2 Minguet J, Smith KH and Bramlage P: Targeted therapies for treatment of non-small cell lung carcinoma-Recent advances and future perspectives. Int J Cancer 138: 2549-2561, 2016.

3 Levy B, Hu ZI, Cordova KN, Close S, Lee K and Becker D: Clinical utility of liquid diagnostic platforms in non-small cell lung carcinoma. Oncologist 21: 1121-1130, 2016.

4 Torre LA, Siegel RL and Jemal A: Lung cancer statistics. Adv Exp Med Biol 893: 1-19, 2016.

5 White NM, Cabanski CR, Silva-Fisher JM, Dang HX, Govindan $\mathrm{R}$ and Maher CA: Transcriptome sequencing reveals altered long intergenic non-coding RNAs in lung cancer. Genome Biol 15: 429, 2014.

6 Pan C, Yao G, Liu B, Ma T, Xia Y, Wei K, Wang J, Xu J, Chen $\mathrm{L}$ and Chen Y: Long noncoding RNA FAL1 promotes cell proliferation, invasion and epithelial-mesenchymal transition through the PTEN/AKT signaling axis in non-small cell lung cancer. Cell Physiol Biochem 43: 339-352, 2017.

7 Geisinger K, Rami-Porta R, Moreira AL, Travis WD and Nicholson AG: Lung cancer staging and grading. In: World Health Organization Classification of Tumors. Pathology and Genetics of the Lung, Pleura, Thymus and Heart. Travis WD, Brambilla E, Burke AP, Marx A and Nicholson AG (eds.). Lyon: IARC Press, pp. 14-15, 2015.

8 Travis WD, Brambilla E and Geisinger KR: Histological grading in lung cancer: One system for all or separate systems for each histological type? Eur Respir J 47: 720-723, 2016.
9 Travis WD, Brambilla E, Noguchi M, Nicholson AG, Geisinger KR, Yatabe Y, Beer DG, Powell CA, Riely GJ, Van Schil PE, Garg K, Austin JH, Asamura H, Rusch VW, Hirsch FR, Scagliotti G, Mitsudomi T, Huber RM, Ishikawa Y, Jett J, Sanchez-Cespedes M, Sculier JP, Takahashi T, Tsuboi M, Vansteenkiste J, Wistuba I, Yang PC, Aberle D, Brambilla C, Flieder D, Franklin W, Gazdar A, Gould M, Hasleton P, Henderson D, Johnson B, Johnson D, Kerr K, Kuriyama K, Lee JS, Miller VA, Peterson I, Roggli V, Rosell R, Saijo N, Thunnissen E, Tsao M and Yankelewitz D: International Association for the Study of Lung Cancer/American Thoracic Society/European Respiratory Society international multidisciplinary classification of lung adenocarcinoma. J Thorac Oncol 6: 244-285, 2011.

10 Woo T, Okudela K, Mitsui H, Tajiri M, Yamamoto T, Rino Y, Ohashi $K$ and Masuda $M$ : Prognostic value of the IASLC/ATS/ERS classification of lung adenocarcinoma in stage I disease of Japanese cases. Pathol Int 62: 785-791, 2012.

11 Yoshizawa A, Motoi N, Riely GJ, Sima CS, Gerald WL, Kris MG, Park BJ, Rusch VW and Travis WD: Impact of proposed IASLC/ATS/ERS classification of lung adenocarcinoma: prognostic subgroups and implications for further revision of staging based on analysis of 514 stage I cases. Mod Pathol 24: 653-664, 2011.

12 Tsao MS, Marguet S, Le Teuff G, Lantuejoul S, Shepherd FA, Seymour L, Kratzke R, Graziano SL, Popper HH, Rosell R, Douillard JY, Le-Chevalier T, Pignon JP, Soria JC and Brambilla EM: Subtype classification of lung adenocarcinoma predicts benefit from adjuvant chemotherapy in patients undergoing complete resection. J Clin Oncol 33: 3439-3446, 2015.

13 Westaway DD, Toon CW, Farzin M, Sioson, Watson N, Brady PW, Marshman D, Mathur MM and Gill AJ: The International Association for the Study of Lung Cancer/American Thoracic Society/European Respiratory Society grading system has limited prognostic significance in advanced resected pulmonary adenocarcinoma. Pathology 45: 553-558, 2013.

14 Weichert W, Kossakowski C, Harms A, Schirmacher P, Muley T, Dienemann H and Warth A: Proposal of a prognostically relevant grading scheme for pulmonary squamous cell carcinoma. Eur Respir J 47: 938-946, 2016.

15 Rami-Porta R, Bolejack V, Crowley J, Ball D, Kim J, Lyons G, Rice T, Suzuki K, Thomas CF Jr., Travis WD and Wu YL.; IASLC Staging and Prognostic Factors Committee, Advisory Boards and Participating Institutions: The IASLC Lung Cancer Staging Project: Proposals for the revisions of the T descriptors in the forthcoming eighth edition of the TNM classification for lung cancer. J Thorac Oncol 10: 990-1003, 2015.

16 Brierley JD, Gospodarowicz MK and Wittekind C (eds): TNM Classification of Malignant Tumours. 8th ed. NJ, WileyBlackwell, 2016.

17 Kanda Y: Investigation of the freely available easy-to-use software 'EZR' for medical statistics. Bone Marrow Transplant 48: 452-458, 2013.

18 Chung CK, Zaino R, Stryker JA, O'Neill M Jr and DeMuth WE Jr.: Carcinoma of the lung: Evaluation of histological grade and factors influencing prognosis. Ann Thorac Surg 33: 599-604, 1982.

19 Swinson DE, Jones JL, Richardson D, Cox G, Edwards JG and O'Byrne KJ: Tumor necrosis is an independent prognostic marker in non-small cell lung carcinoma: correlation with biological variables. Lung Cancer 37: 235-240, 2002. 
20 Colby TV, Ohori P, Jambhekar NA, Noguchi M, Rami-Porta R, Petersen I, Henschke C, Franks T, Takahashi T, Vazquez MF, Shimosato Y, Kawai T, Geisinger K, Matsuno Y, Meyerson M, Yokose T, Khoor A, Hanash SM, Westra WH and Jen J: Adenocarcinoma. In: World Health Organization Classification of Tumors. Pathology and Genetics of the Lung, Pleura, Thymus and Heart. Travis WD, Brambilla E, Müller-Hermelink HK and Harris CC (eds.). Lyon, IARC Press, pp. 35-44, 2004.

21 Sica G, Yoshizawa A, Sima CS, Azzoli CG, Downey RJ, Rusch VW, Travis WD and Moreira AL: A grading system of lung adenocarcinoma based on histologic pattern is predictive of disease recurrence in stage I tumors. Am J Surg Pathol 34: 1155$1162,2010$.

22 Hung JJ, Jeng WJ, Chou TY, Hsu WH, Wu KJ, Huang BS and Wu YC: Prognostic value of the new International Association for the Study of Lung Cancer/American Thoracic Society/ European Respiratory Society lung adenocarcinoma classification on death and recurrence in completely resected stage I lung adenocarcinoma. Ann Surg 258: 1079-1086, 2013.

23. Xie X, Liu HT, Mei J, Ding FB, Xiao HB, Hu FQ, Hu R and Wang MS: LncRNA HMlincRNA717 is down-regulated in nonsmall cell lung cancer and associated with poor prognosis. Int $\mathrm{J}$ Clin Exp Pathol 7: 8881-8886, 2014.

24. Mattin B, Paesmans M, Mascaux C, Berghmans T, Lothaire P, Meert AP, Lafitte JJ and Sculier JP: Ki-67 expression and patients survival in lung cancer: systemic review of the literature with meta-analysis. Br J Cancer 91: 2018-2025, 2004.
25. Rakha EA, Reis-Filho JS, Baehner F, Dabbs DJ, Decker T, Eusebi V, Fox SB, Ichihara S, Jacquemier J, Lakhani SR, Palacios J, Richardson AL, Schnitt SJ, Schmitt FC, Tse GM, Badve S and Ellis IO: Breast cancer prognostic classification in the molecular era: the role of histological grade. Breast Cancer Res 12: 207, 2010.

26. Amin MB, Lin DW, Gore JL, Srigley JR, Samaratunga H, Egevad L, Rubin M, Nacey J, Carter HB, Klotz L, Sandler H, Zietman AL, Holden S, Montironi R, Humphrey PA, Evans AJ, Epstein JI, Delahunt B, McKenney JK, Berney D, Wheeler TM, Chinnaiyan AM, True L, Knudsen B and Hammond ME: The critical role of the pathologist in determining eligibility for active surveillance as a management option in patients with prostate cancer: consensus statement with recommendations supported by the College of American Pathologists, International Society of Urological Pathology, Association of Directors of Anatomic and Surgical Pathology, the New Zealand Society of Pathologists, and the Prostate Cancer Foundation. Arch Pathol Lab Med 138: 1387-1405, 2014.

27 Cornejo KM, Dong F, Zhou AG, Wu CL, Young RH, Braaten K, Sadow PM, Nielson GP and Oliva E: Papillary renal cell carcinoma: correlation of tumor grade and histologic characteristics with clinical outcome. Hum Pathol 46: 1411-1417, 2015.

Received July 17, 2018

Revised August 7, 2018

Accepted August 9, 2018 